UJBM, Vol. 3, No. 1, January - June 2004, pp 76-85 ISSN 0975-3311 | https://doi.org/10.12725/ujbm.4.9

\title{
CHANGING PROFILE OF RURAL MARKETING EMERGING DIMENSIONS OF RURAL CONSUMERS BEHAVIOUR
}

C. Rajendra Kumar*, Sanjay S. Kaptan**

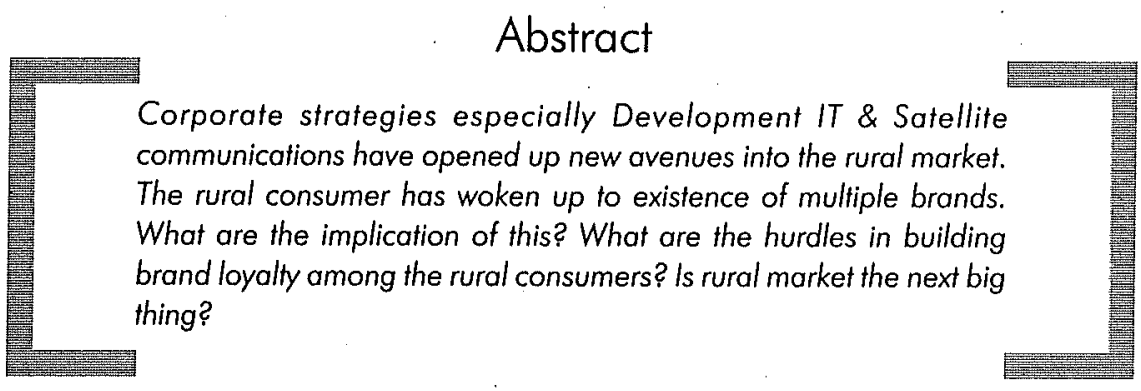

Today the Indian rural market is regarded as the biggest hope of demand recovery. Marketers and manufacturers have realized the burgeoning purchase power, vast size and demand base of the neglected hinterland. Now efforts are on to accentuate the attitude of the rural consumer. The marketing mix of many companies are being tailored to suit rural taste and life style. The indigenous companies are not only concentrating their marketing activities, but the MNCs also have reached in remote rural areas at present. The government policies, development of Information Technology, corporate strategies and satellite communication are the factors responsible for the developed rural marketing.

* Research Scholar.

** Director, Department Business Admin and Management, Amravati University, Amaravati. 
The sudden lure of rural India can be attributed to the socio-economic changes sweeping rural areas today. These changes can be linked to an increase in productivity in the farm sector. Following agricultural revolutions green or white - the yield per acre or annual increased substantially. This was largely due to the application of technology to the farm sector and using modern farming methods. Formation of co-operatives in Western and Southern India also helped the farmer to increase farm productivity. Companies and banks adopting villages for an integrated rural development also accelerated the process of income generation thus creating hope for better standards of living. The Integrated Rural Development Programme has education, health, modern farming practices, land development and cooperative marketing of produce as its pillars. Development of village industry and craft is also another component of this programme. All these changes meant more income, higher aspirations and changing life-styles in rural India.

\section{Changing Profile of Rural Marketing}

Macro-economic numbers cannot capture all the nuances of our multi-faceted economy. But they do serve as useful markers to the big geographical markets in the country. And if it is the big picture you are looking for, look no further than NCAER's India. Market Demographics Report (IMDR) 2002 and of course, the 2001 census, the table below shows Indian house hold distribution of income.

\section{Indian Household Distribution of Income}

A Urban-Rural Comparison

\begin{tabular}{|c|c|c|c|}
\hline \multicolumn{2}{|c|}{ URBAN } & \multicolumn{2}{|c|}{ RURAL } \\
\hline $\begin{array}{l}\text { Income } \\
\text { Rs. }\end{array}$ & $\begin{array}{c}\text { No. of } \\
\text { House Holds \% }\end{array}$ & $\begin{array}{l}\text { Income } \\
\text { Rs. }\end{array}$ & $\begin{array}{c}\text { No. of } \\
\text { House Holds \% }\end{array}$ \\
\hline Up to 35,000 & 19.02 & Upto 35,000 & 52.83 \\
\hline $35,001-70,000$ & 39.26 & $35,001-70,000$ & 35.58 \\
\hline $70,001-1,05,000$ & 22.48 & $70,001-1,05,000$ & 8.39 \\
\hline $1,05,001-1,40,000$ & 10.76 & $1,05,001-1,40,000$ & 2.59 \\
\hline Above $-1,40,000$ & 8.48 & Above - $1,40,000$ & 0.61 \\
\hline $\begin{array}{l}\text { Total No. of } \\
\text { House Holds ('000) }\end{array}$ & 4,621 & $\begin{array}{l}\text { Total No. of } \\
\text { House Holds ('000) }\end{array}$ & 10,965 \\
\hline
\end{tabular}

Source : India Market Demographics Report of NCAER (2002) 
There are many challenges that the companies face in tackling rural markets understanding rural consumers, reaching products and services to remote rural locations and communicating with vastly heterogeneous rural audiences. Sadly not many companies have invested sufficient money in research or time to understand rural-consumers, their values, aspirations, needs and usage habits. Marketing is all about "know your customer" - but having largely ignored this cardinal principle, success has eluded most corporations in rural markets.

An Income dispersal projection by NCAER for 2006-07 says that the number of poor house holds in India will shrink by half to 28 million households from 61 million in 1997-98. In this period middle income house holds will double, rich house holds will treble. This upward push will lead to greatly increased purchasing power. Today's non-consumer, comprising the rural poor, will enter the market in large numbers as first-time buyers.

Getting a large share of this growing - rural pie will call for a radical shift in the way managers think; from gross managers to high profits", from high value unit sales to a game of high volumes, capital efficiency and from an one-solution-fitsall mentality to market innovation.

Rural India's Income Classes by size over different Time Periods

\begin{tabular}{l|c|c|c|c|c|c|}
\hline \multirow{2}{*}{ Different Classes } & \multicolumn{2}{|c|}{$1995-96$} & \multicolumn{2}{c|}{$2001-2002$} & \multicolumn{2}{c|}{$2006-2007$} \\
\cline { 2 - 7 } & $\begin{array}{l}\text { House } \\
\text { Holds }\end{array}$ & Populations & $\begin{array}{l}\text { House } \\
\text { Holds }\end{array}$ & Populations & $\begin{array}{l}\text { House } \\
\text { Holds }\end{array}$ & Populations \\
\hline The Very Rich & 0.4 & 2 & 0.7 & 4 & 1.2 & 7 \\
The Consuming & 15.9 & 92 & 19.9 & 115 & 34.8 & 202 \\
Class & 37.3 & 216 & 57 & 331 & 68.1 & 395 \\
The climbers & 36.9 & 214 & 29.3 & 170 & 19.5 & 113 \\
The aspiranits & 27.7 & 161 & 21.4 & 124 & 15.5 & 90 \\
The destitute & \multicolumn{3}{|c|}{ Note: All figures are in million } \\
Source: NCAER
\end{tabular}

\section{Few Behavioural Issues of Indian Consumers}

An understanding of Indian consumers is essential in formulating rural marketing strategies. However, information about rural consumers is limited and hazy due to lack of competence, partial approach and limited knowledge and bias of the 
corporate managers. The model of consumer behaviour comprises stimuli both internal and external, which include self, socio-cultural, technological, economic and political factors. In the rural social customs and sanctions, caste factor, temporary employment, difficulty in accounting incomes, influence of development groups and opinion leaders like teacher, Mandal Pradhan, Gram Sarpanch, group leaders, officials, size of the family, status (leader, elected politician, teacher etc.), sociability, latest technology products and government policies and programmes act as generators of stimuli.

\section{The Rural Wall:}

When KSA Technopark conducted its maiden rural consumer outlook in 2003 , it found that unlike their urban counterparts, rural consumers do not distinguish between occupational and personal spending. That because $70-80 \%$ of rural consumers are farmers, who are in a way, self-employed businessmen. From whatever they earn, they have to spend on the house hold as well as on the upkeep of the farm. As a result, their spending basket not only consists of personal and house hold items but also occupational expenditure like fertilizers, seeds, pesticides and so on. This rural wallet has been given below table.

Occupational and personal spending of rural consumers

\begin{tabular}{|l|c|l|l|l|l|}
\hline Items & Percent & Items & Percent & ltems & Percent \\
\hline Groceries & $26.5 \%$ & $\begin{array}{l}\text { Entertainment/ } \\
\text { Music }\end{array}$ & $3 \%$ & Home & $1 \%$ \\
Personal case & $4 \%$ & $\begin{array}{l}\text { Hard liquor } \\
\text { Tobacco }\end{array}$ & $4 \%$ & $\begin{array}{l}\text { House hold } \\
\text { Maintenance }\end{array}$ & $2 \%$ \\
Medicines/ & $8 \%$ & $\begin{array}{l}\text { Home } \\
\text { Appliances } \\
\text { Health care }\end{array}$ & $0.5 \%$ & Agri inputs & $13 \%$ \\
Fuel & $6 \%$ & $\begin{array}{l}\text { Vehicles } \\
\text { Savings/ } \\
\text { Interest }\end{array}$ & $6 \%$ & $5 \%$ & Jewellery \\
Repayment & $6 \%$ & $3 \%$ & \\
\hline
\end{tabular}

Source: KSA Technopark's Rural consumer outlook 2003

\section{Few Behavioural Issues of Indian Consumers}

- There has been a spectacular change in the income level pattern especially with reference to lower middle and middle-income group. The percentage of house hold in the middle and lower middle income category is likely to soar 
from $41 \%$ in $1997-98$ to $64 \%$ in the year $2006-07$. This envisages not only improvement in life style of the house holds but also a steep increase in disposable income.

- The National Readership survey for the year 2002 says the newspaper readership has grown by $10 \%$ over the last two years, almost half of the growth $(48 \%)$ come from rural areas. It also says Hindi dailies extended their reach in urban India by nearly $19 \%$ in the last 3 years and in rural India by $38 \%$ in the same period. It is to be noted that this has happened inspite of the on slaught of cable and satellite channels.

- About $94 \%$ of developed (including Punjab, Haryana, Gujarat, Maharashtra, Goa, Karnataka, Kerala and Tamil Nadu) and about $85 \%$ of the developing rural markets including Assam, West Bengal, Andhra Pradesh, Bihar, Uttar Pradesh, Madhya Pradesh, Orissa and Rajasthan have given importance for necessities such as toilets soaps, washing powder, tea, batteries, soap etc. while it is $30-45 \%$ in categories like coffee, shampoo, biscuits, hair oils, toothpaste and talcum powder which are called as emerging products.

- The rural buyer is less educated when compared to his urban counter parties price sensitive, more traditional and is a keen viewer of television and video programmes. The products for rural markets have to be simpler, easy to use, visually identifiable, affordable, communicated in an interesting style and available at the customer's door step.

- According to the ORG's National Readership Survey, $36 \%$ of the rural adult population has the habit of viewing cinema even though the frequency varies widely. Among the rural viewers, $10 \%$ go to cinema once a week, $33 \%$ once a month, 22 per cent three to four times in a year and the remaining $35 \%$ less frequently.

A study conducted by SRI a specialist unit of market research house IMRD revealed the following points:

1. The pattern of buying and aptitude clearly shows that the rural market is totally different from the urban market.

2. There is more conspicuous consumption of consumer durables by almost all segment of rural markets.

3. Rural market will throw up as much as $60 \%$ of the demand for consumer durables in the next five years. 
4. Transportation durables preceeded consumer electronic products. Bicycle was way áhead with a market penetration of $73 \%$.

5. Those who given higher priority to consumer electronic products are the more educated and affluent.

- Marketing genius describe rural markets as the markets of the new millennium. According to them marketers will have to understand the rural customers before they can make in-roads into rural markets.

- Rural India's hunger for consumer goods supported by rising incomes and changing tastes is on the rise, according to a survey by a leading independent think tank. The rural consumers are also moving away from unbranded to branded products.

\section{Rural Consumers in India}

Rural consumers are fundamentally different from their urban counterparts socially, psychologically, physiologically and literally. The special characteristics of the rural consumers in India are listed below:

- Rural consumers buy only inexpensive products. There is mass consumption among them regarding a particular product or brand since they are homogeneous at village or regional level.

- In rural market, since the women have very little contact with the market, the male makes the purchase decision. The community decision-making is quite common in a rural market because of strong caste and social structures and low literacy levels.

- Rural consumers generally feel inhibited and ill-equipped to buy confidently since they have only lesser exposure to the product quality, service support and company credentials.

- A rural consumer may be illiterate as per the census definition, but he is not unintelligent. The proliferation of television channels, opinion leaders village youth who go to cities for education and employment and school going children have greatly added to his knowledge on various products and subjects.

- The brand awareness, preference and loyalty among the rural consumers is comparatively less than their urban counterparts. The degree of brand loyalty 
varies among the rural consumer according to the nature of products. If the rural consumers are loyal to one brand, it is very difficult to change.

\section{Consumer Behaviour}

Consumer behavior is the act of individuals in obtaining and using goods and services which is exhibited through their decision process. Consumer purchases are likely to be influenced by physiological and sociological factors.

Consumer behaviour is the process whereby individuals decide what, when, where, how and from whom to purchase goods and services. The stages of buying behaviour are:

1. Feeling the need

2. Pre-purchase activities

3. Final decisions on purchase and actual buying

4. Using the product and post purchase feeling

The rural consumer behaviour aspects such as consumer information, source, place of purchase, brand awareness, media habits, brand loyalty, brand switching influence purchase decision.

\section{Consumer Information Source}

The use of mouth to mouth source of information by consumers in rural areas is greater when compared to those in urban areas. The information source used by consumer depends to those in urban areas. The information source used by consumer depends upon the degree of ruralisation. The information sources are news papers, point of purchase (ads), television, cinema, video on wheels etc. Apart from these, the role of opinion leaders, product demonstration, friends, well informed relatives, educated youth and local retailers play their own role as a consumer information source.

\section{Place of Purchase}

The place where consumer buys is important for a marketer to design his distribution strategy because if the product is not made available at the place where the consumer normally does not make brand discrimination but once induced to buy and use a product, the consumer becomes loyal to the brand provided he is satisfied about its 
functional utility. Such a loyal user may even make efforts to get the whole village to use it. The rural consumer has low awareness of the different brands. This is possibly due to television not considered an effective media to reach consumers in rural markets. The limited number of brands in rural market shows that the consumers are more likely to buy the same brand than try new brands. The rural buyers are more of habitual buyers than variety seekers. The benefits of economy is more important to rural buyers. Rural market is proving a difficult market. It is easy to build a label here using ads but the emotional connect inherent in brand building is difficult to do largely due to the prohibitively high media cost per rural contact $V_{s}$ mass media's sheer reach and low cost per thousand ratio.

\section{Brand Loyalty}

Brand loyalty signifies a repeat purchase of the brand. Apart from this store loyalty; purchasing power, influence of opinion leaders, among other can play an equally important role in determining brand loyalty. In rural markets, where infrastructure still poses a problem for marketers, even after significant improvements in the recent past, retailing is still in the traditional mode, where people are more important than anything else. The influence of retailers is comparatively higher in creation of brand loyalty. The newly empowered rural consumers are less loyal as they are yet to develop brand beliefs due to their inability in fixing up demand standards of value from brand. The bombardment of television campaigns is likely to create confusion rather than generate comprehension. The rural markets are still evolving in terms of consolidation of consumer attitudes towards brand with price sensitivity still being a barrier for the marketers.

\section{Brand Switching}

Brand switching is a growing phenomenon in the globalized marketing environment. The inflow of new brands with new features and additional benefits attract the consumers to switch to the new brand. But the situation in Rural India is different. Ineffective promotional exercises, lack of efficiency in the distribution networks, conventional purchasing system, poor reach of the media etc. turn out to be the reasons for brand switching. The rural consumers are mostly missed by the media reach of even the powerful brands. They are guided by the advice of the opinion leaders and retailers. So the rural consumers have more store loyalty as compare to the brand loyalty. This means they switch brands according to the advice of retailers and opinion leaders. 


\section{Factors Influencing Rural Consumer Behaviour}

The rural consumer behaviour is influenced by several aspects namely socioeconomic, cultural, psychological and physiological environment. Various aspects are decided by the level of education of consumers. Apart from these, the rural consumer behaviour is moulded by the external environment namely opinion leaders, friends and relatives, resource persons, retailers, reach of media, caste and religion etc. The behaviour of the rural consumer depends upon the product he wants to purchase. The behaviour is highly dynamic even in the consumption of one single product. The complexities of Rural consumer behaviour are shown in the above figures.

\section{Conclusion}

To conclude, the rural market today is not just for products like fertilizers and pesticides but offers significant opportunities for all consumer goods (both non durable and durable). The most interesting aspect in the rural market is that it is growing at an astounding of $25 \%$ per annum. It is this opportunity that all markets now want to grab. The success of the rural initiatives taken by a few firms has

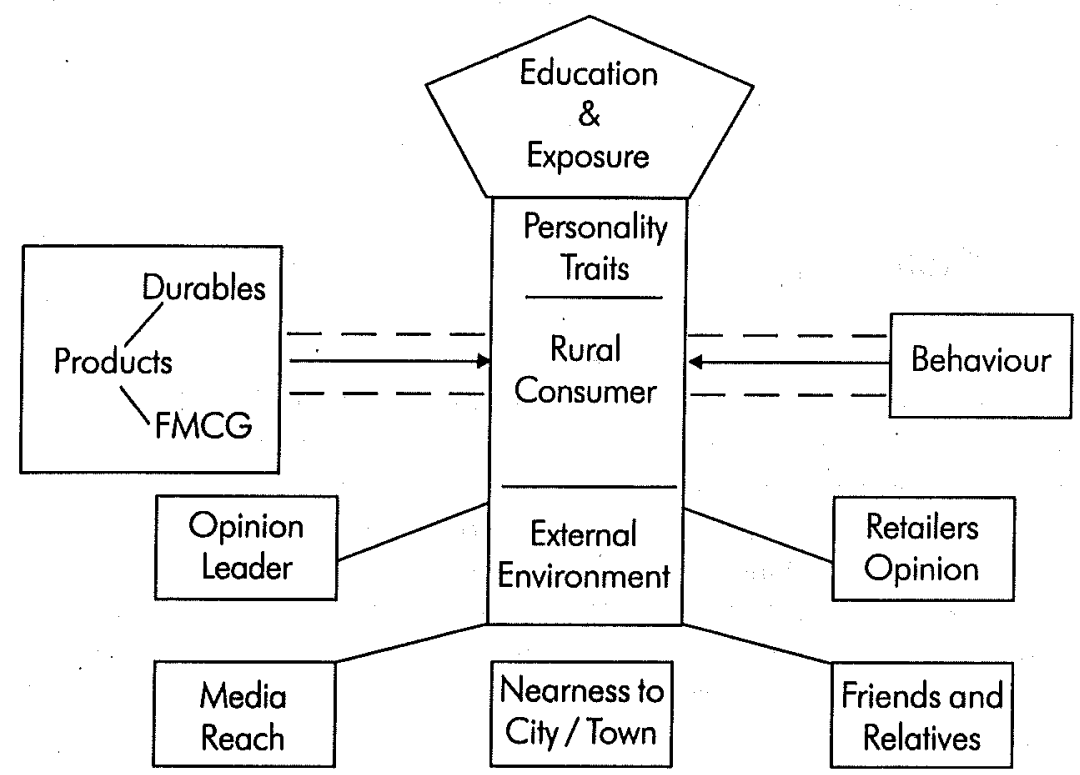


opened the eyes of other marketers to the vast potential of rural markets. The understanding of rural consumer and rural market is highly essential for the corporates. More rural research studies should be undertaken to understand rural consumers better and generate more reliable data on the rural sector. The marketing strategies are to be framed according to the need of rural consumers and it is to be properly communicated to them because the next big marketing revolution could happen in the rural sector.

\section{References:}

1. India market Demographics Report of NCAET (2002)

2. KSA Technopark's Rural consumer outlook 2003

3. Manorama year book 2003

4. Pradeep Kashyap - CEO of MART, Selling to the Hinterland, The marketing whitebook of Business World 2003-04

5. Suresh K. Pradeep Sasyap: Rurap people look up to urbanites A \& M 15, Jan 2000

6. Anupam Jain, Mind those Ps in Rural Markets - Economic Times, May 31, 1999

7. Kumar Samal, "Urban Reference and Divided Rural Market: Searel for a frame work" Indian Journal of Marketing April 1995

8. Ganesh P "Brand Switching": A study of Rural consumers" Udyog pragate April-June 2003.

9. Sorwade, WK "Emerging Dimensions of Buyer Behaviour in Rural Area" Indian Journal of Marketing Jan - Feb 2002. 